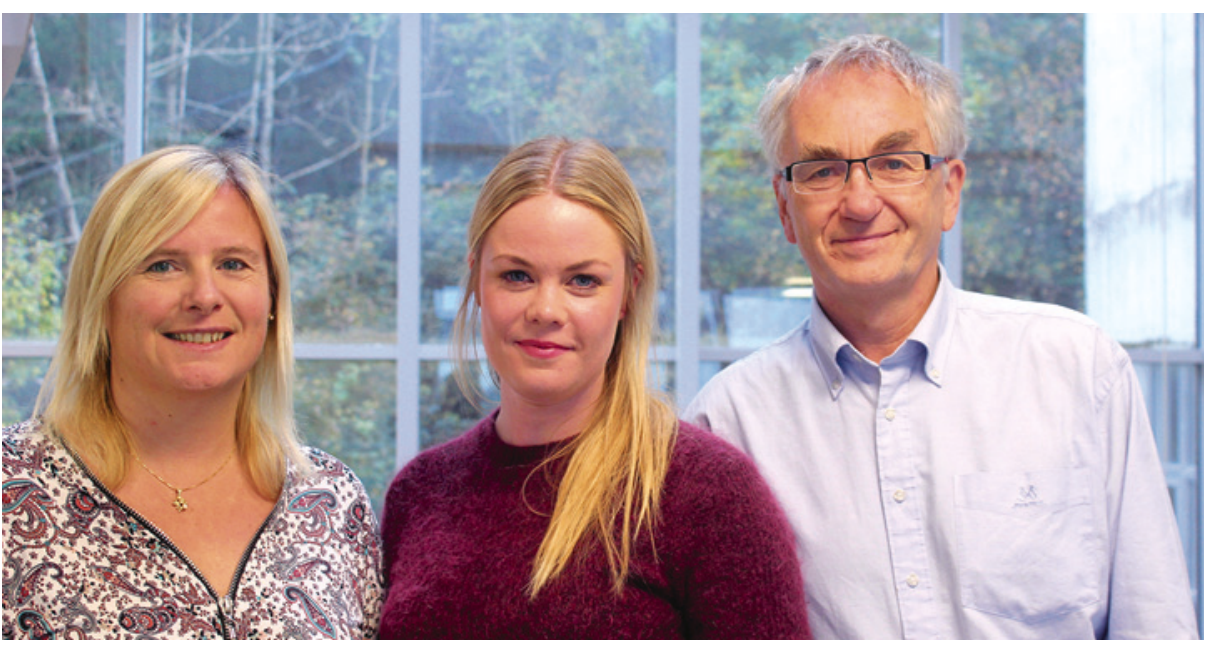

Frå venstre Anne Stavelin, Tone Bukve, Sverre Sandberg. Foto: Brith Helen Bjelkarøy

\title{
Betre kvalitet \\ med nasjonalt kvalitetssystem
}

Kvaliteten på laboratorieanalysar i primærhelsetenesta blir betre ved å delta i eit nasjonalt kvalitetssystem over tid. Det syner ein ny norsk studie.

Omgrepet «pasientnær analysering» tyder at laboratorieprøvar blir analyserte nær pasienten med små, enkle instrument. Svaret kjem med ein gong. Det er vist at kvaliteten kan variere betydeleg ved slik analysering, og i nokre land har ein difor etablert system for å kontrollere kvaliteten på analysane. I Noreg driv Norsk kvalitetsforbedring av laboratorievirksomhet utenfor sykehus (Noklus) det nasjonale kvalitetssystemet for pasientnær analysering.

Ein veit lite om deltakinga og om måten kvalitetskontrollprogramma blir drivne på er effektive for å sikre god analysekvalitet. Difor gjennomførte forskarar frå Noklus ein studie for å sjå om analysekvaliteten i primærhelsetenesta i Noreg blir betre av å delta i Noklus over tid. Dei ville òg identifisere kva faktorar som er viktige for å oppnå god analysekvalitet.

Forskarane henta data om analysekvaliteten av C-reaktivt protein (CRP), glukose og hemoglobin frå dei eksterne kvalitetsvurderingsprogramma til Noklus frå 2006 til 2015. I tillegg vart informasjon om instrument og ulike praksiskarakteristika henta ut. For å vurdere faktorar assosierte med god analysekvalitet vart det gjennomført ein logistisk regresjonsanalyse.

Resultata viste at sannsynet for å få vurderinga «meget god analysekvalitet» auka jo lenger ein deltok i kvalitetssystemet. Andre faktorar som også var assosierte med god analysekvalitet var type instrument som vart nytta, at ein utførte intern analytisk kvalitetskontroll kvar veke, at ein utførte ti eller fleire pasientprøvar kvar veke og at det var ein bioingeniør som gjorde analysane. Ein del faktorar som ikkje vart registrerte, t.d. besøk av laboratoriekonsulent frå Noklus og deltaking på kurs, har truleg også innverknad på den påviste kvalitetsforbetringa.

Studien er nylig publisert i tidsskriftet Clinical Chemistry (1). Funna er viktige for å kunne optimalisere og effektivisere arbeidet med å sikre høg kvalitet på laboratorietenestene i primærhelsetenesta.

\section{Forskargruppa}

Studien er utført i forskingsgruppa Kunnskapsbasert bruk og nytte av laboratorieanalysar ved Noklus, Haraldsplass Diakonale sykehus, Bergen. Førsteforfattar Tone Bukve vart tilknytt forskingsgruppa gjennom forskarlina ved Universitetet i Bergen. Ho har dei siste åra drive forsking på pasientnær analysering. Anne Stavelin er bioingeniør og forskar i Noklus og har ein ph.d.-grad i analytisk kvalitetskontroll i primærhelsetenesta. Ho er dessutan leiar av European Organisation for External Quality Assurance Providers in Laboratory Medicine (EQALM). Sverre Sandberg er leiar av Noklus, professor ved Universitetet i Bergen, overlege ved Haukeland universitetssjukehus og leiar av forskingsgruppa.

\section{Inge Rasmus Groote}

Tidsskriftet

\section{Litteratur}

1. Bukve T, Stavelin A, Sandberg S. Effect of Participating in a Quality Improvement System over Time for Point-of-Care C-Reactive Protein, Glucose, and Hemoglobin Testing. Clin Chem 2016; 62: 1474-81.

\section{Fagtermar}

Ekstern kvalitetsvurdering: Kontrollprogram for å vurdere analysemetodar og analysekvaliteten ved laboratoriet, utført ved hjelp av kontrollmateriale med ukjend fasitverdi for deltakarane. Deltakarane analyserer kontrollmateriale og sender resultata til ein ekstern part, t.d. Noklus, som arbeider statistisk med resultata og gjev skriftleg tilbakemelding om resultata.

Intern analytisk kvalitetskontroll: Rutinar som laboratoriet har for å overvake og vurdere analysekvaliteten kontinuerleg. Kontrollen blir utført ved hjelp av kontrollmateriale med kjend fasitverdi.

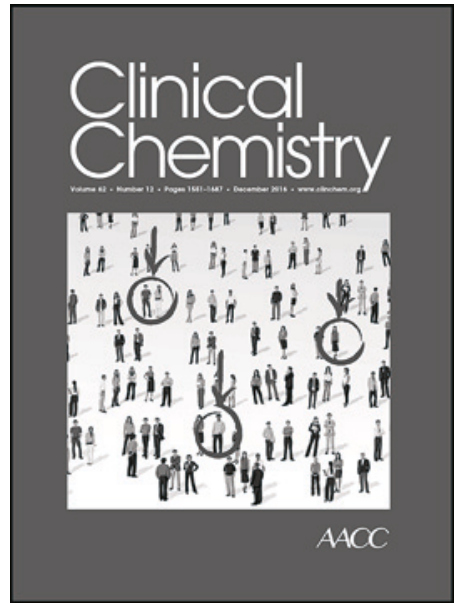

Studien vart e-publisert i tidsskriftet Clinical Chemistry i september 2016 